\title{
Comorbidity in a group of vascular stroke patients and the reliability of the cumulative illness rating scale
}

\section{Bir grup vasküler inme hastasında komorbidite ve kümülatif hastalık değerlendirme skalasının güvenirliği}

Nurdan Paker, Derya Buğdaycı, Gökşen Gökşenoğlu, Demet Tekdöş

Department of Physical Medicine and Rehabilitation, İstanbul Physical Medicine and Rehabilitation Training and Research Hospital, İstanbul, Turkey

Received / Geliş tarihi: September 2015 Accepted / Kabul tarihi: February 2016

\begin{abstract}
Objectives: This study aims to investigate the reliability of the Cumulative Illness Rating Scale (CIRS) and the frequency of comorbidity in stroke.

Patients and methods: Fifty-two consecutive patients who had stroke once ( 25 males, 27 females; mean age $65.6 \pm 9.9$ years; range 37 to 83 years), admitted to the stroke unit of the rehabilitation hospital between 01.09.2011 and 31.12.2011, were included in this study. After the first evaluation, three physicians scored the CIRS from the medical records. The same three physicians repeated this process after a one-week interval. Intraclass correlation coefficients were calculated for the measurement of intra-rater and inter-rater reliability studies.

Results: Mean CIRS score was $16 \pm 4.4$. Mean number of the affected organ systems was $6.8 \pm 1.8$ (range, 4-12). The intraclass correlation coefficients were between $0.97-0.99$. The most common chronic conditions associated to stroke were vascular problems, endocrine and metabolic disorders and psychiatric problems.
\end{abstract}

Conclusion: As a result, both the intra-rater and inter-rater reliability results of the CIRS were very good in stroke. The patients with stroke had six system problems as a mean in this study.

Keywords: Comorbidity; cumulative illness rating scale; reliability; stroke.

\section{$\ddot{O Z Z}$}

Amaç: Bu çalışmada inmede Kümülatif Hastalık Değerlendirme Skalası (KHDS)'nın güvenirliği ve komorbidite sıklığı araştırıldı.

Hastalar ve yöntemler: 01.09.2011 - 31.12.2011 tarihleri arasında rehabilitasyon hastanesinin inme ünitesine başvuran bir kez inme geçirmiş olan 52 ardışık hasta (25 erkek, 27 kadın; ort. yaş 65.6 99.9 yıl; dağılım 37-83 yıl) çalışmaya alındı. İlk değerlendirme sonrasında üç doktor KHDS'yi tıbbi kayıtlardan ayrı ayrı puanladı. Bu işlem bir hafta sonra aynı doktorlar tarafından tekrarlandı. Aynı değerlendirmecinin farklı ölçümlerindeki ve farklı değerlendirmeciler arasındaki güvenirlik çalışmaları için sınıf içi korelasyon katsayıları hesaplandı.

Bulgular: Ortalama KHDS skoru $16 \pm 4.4$ idi. Etkilenen organ sistem sayısı ortalama olarak $6.8 \pm 1.8$ (dağılım, 4-12) bulundu. Sınıf içi korelasyon katsayısı 0.97-0.99 arasında idi. İnmeyle birlikte en sık görülen kronik durumlar vasküler bozukluklar, endokrin ve metabolik bozukluklar ve pisikiyatrik problemlerdi.

Sonuç: Sonuç olarak, inmede KHDS’nin hem değerlendirme yapan kişinin farklı̈ ölçümlerindeki hem de farklı değerlendirmeciler arasındaki güvenirliği çok iyi idi. Bu çalışmada inmeli hastalarda ortalama olarak altı sistem problemi ile karşılaşıldı.

Anabtar sözcükler: Komorbidite; kümülatif hastalık değerlendirme skalası; güvenirlik; inme.

Stroke occurs frequently in older people and may result in neurological deficits. Stroke patients also have comorbidity which is defined as the coexistence of more than one different condition in the same individual. ${ }^{[1]}$ Although comorbidity may be observed at any age, its prevalence increases with age. ${ }^{[2-4]}$ The prevalence of multiple diseases amongst older people can be as high as $55-98 \%{ }^{[5]}$ 
Some co-occurring disorders are more common in elderly people. ${ }^{[6-10]}$ While some chronic disorders coexist due to a common mechanism of pathogenesis; such as diabetes mellitus and related vascular problems, some disorders may coexist in spite of the lack of a determined common underlying pathogenic mechanism in patients with comorbidity. In a recent study, the most common cluster of diseases in elderly people was suggested to be vascular disorders such as hypertension, cardiac failure, atrial fibrillation and cerebrovascular disorders. ${ }^{[6]}$ In other studies, the association of cardiovascular and metabolic disorders and the association of the metabolic and neurological disorders were also reported to be common among elderly people..$^{[7,8]}$

Comorbidity may be related to the factors such as age, gender, education level, marital status, family structure and lower socioeconomic status. ${ }^{[5,8]}$ The identification of these characteristics may be useful in terms of identifying and implementing preventive measures. ${ }^{[2]}$ Comorbidity may result in the deterioration of functional status, quality of life, frequent hospital admission and increased health related expenses. ${ }^{[5,11]}$ The relationship between comorbidity and mortality risk is not clear. ${ }^{[5]}$ Cumulative Illness Rating Scale (CIRS) is one of the most frequently used scales for defining the multiple conditions. ${ }^{[12]}$ It was developed by Linn et al. ${ }^{[13]}$ for measuring comorbidity with a score ranging from 0 to 4 based on every item relating to the 13 systems. The CIRS was modified by Miller at al., ${ }^{[14]}$ to investigate problems related to the 14 systems including cardiac, vascular, hematological, respiratory, otorhinolaryngologic, upper gastrointestinal, lower gastrointestinal, hepatic and pancreatic, renal, genitourinary, musculoskeletal and dermatologic, neurologic, endocrine, metabolic, breast and psychiatric systems. Every system is assessed on a five point Likert scale: $0=$ no problem, $1=$ current minor problem or past significant problem, $2=$ moderate problem or morbidity requiring first line therapy, $3=$ severe problem, constant disability, hard to control chronic problem, and $4=$ extremely severe problem requiring immediate treatment; organ failure or severe functional impairment. ${ }^{[15]}$ So the maximum total score is 56 . Higher scores indicate severity of comorbidities.

The CIRS showed a good level of reliability according to previous studies in geriatrics, geriatric psychiatry, chronic disability, oncology and primary care. ${ }^{[13-18]}$ According to our knowledge, intra-rater and inter-rater reliability of CIRS were not studied in Turkey.
The primary aim of this study was to investigate the intra-rater and inter-rater reliability of CIRS in patients with stroke. Secondarily, we aimed to assess the frequency of comorbidity in stroke.

\section{PATIENTS AND METHODS}

Fifty-two patients (25 males, 27 females; mean age $65.6 \pm 10.0$ years; range 37 to 83 years) with stroke, who were admitted to the inpatient stroke unit of a Rehabilitation Hospital between 01.09.2011 and 31.12.2011, were included in this study. Inclusion criteria were being $\geq 18$ years old and having ischemic or hemorrhagic stroke. Patients with cerebral disorders due to traumatic, tumoral and infectious etiologies were excluded. After physical examination, all medical records were completed by the same physician. Three physicians completed the CIRS twice in one week intervals using medical records. At the baseline, the three physicians read the scoring guide that has been prepared by Hudon et al. ${ }^{[19]}$ The questions in the scale ask about system related problems. They have no specific questions. Before we translated the scoring guide into Turkish, we received permission from the establishers of the scale. Fourteen systems are questioned in modified CIRS.

This study was approved by the İstanbul Physical Medicine and Rehabilitation Training and Research Hospital Ethics Committee. Informed consent was obtained from the patients.

\section{Statistical analysis}

Statistical analyses were performed using SPSS version 13.0 (SPSS Inc., Chicago, IL, USA) software package. The data has been defined using tests as average, standard deviation, median and frequency. Intraclass correlation coefficients were used for the calculation of intra-rater and inter-rater reliability. Raosoft sample size calculator was used for the calculation of the sample size. We treat approximately 160 patients with stroke a year. We estimate the comorbidity rate as $95 \%$ in stroke. Sample size power analysis was $100 \%$.

\section{RESULTS}

Time since stroke was $6.7 \pm 2.8$ (range, 2-12) months. Mean body mass index was $27.9 \pm 4.8$ (range, 19-40) $\mathrm{kg} / \mathrm{m}^{2}$. Education duration was $3.8 \pm 3.9$ (range, $0-15)$ years as mean. Forty-two patients $(81 \%)$ were married and 10 (19\%) were single. The CIRS scores completed by the three physicians are summarized in 
Table 1. Cumulative Illness Rating Scale total scores

\begin{tabular}{llccc}
\hline Measurement & & Median & Mean \pm SD & Min-Max \\
\hline Baseline & 1. physician & 15 & $16.0 \pm 4.4$ & $9-33$ \\
& 2. physician & 15 & $15.6 \pm 4.2$ & $9-31$ \\
\multirow{5}{*}{ One week } & 3. physician & 15 & $15.8 \pm 3.9$ & $9-31$ \\
& 1. physician & 16 & $16.5 \pm 4.4$ & $10-33$ \\
& 2. physician & 16 & $16.0 \pm 4.1$ & $10-31$ \\
& 3. physician & 16 & $15.8 \pm 3.8$ & $10-32$ \\
\hline
\end{tabular}

SD: Standard deviation; Min: Minimum; Max: Maximum.

Table 1. Mean CIRS total scores which were assessed by three physicians were between 15.6-16.0 in the first evaluation. Mean number of the affected systems were $6.8 \pm 1.8$ (range, $4-12$ ).

The intraclass correlation coefficients (ICC) were 0.99 (0.98-0.99), 0.96 (0.94-0.98) and 0.97 (0.96-0.98) for the intra-rater reliability of the CIRS measured by the three physicians, respectively. The ICCs were 0.96 (0.94-0.97) and 0.95 (0.93-0.97) for the interrater reliability of the CIRS for the first and second measurements, respectively. Cronbach's alpha for the internal consistency reliability was 0.95-0.96.

The most common causes of comorbidity in patients with stroke were $94.2 \%$ vascular, $76.9 \%$ endocrine and $69.2 \%$ psychiatric disorders (Figure 1).

\section{DISCUSSION}

In this study both the inter-rater and intra-rater reliability of CIRS were very good. The ICC ranged from 0.96 to 0.99 for the intra-rater reliability, ICC for the inter-rater reliability was $0.95-0.96$. We determined that CIRS is a reliable test with good intra-rater and inter-rater reliability.

The reliability of CIRS was studied in a family practice setting. In a previous study, patient records were assessed and CIRS scores completed by the educated nurses for the reliability study. In the same study, ICC was reported as $0.78-0.80$ and 0.80-0.89 for the inter-rater and intra-rater reliability, respectively. ${ }^{[15]}$ Extermann et al. ${ }^{[16]}$ concluded that the inter-rater reliability of CIRS was between 0.91-0.99 in patients with oncologic problems. Moreover, the validity of CIRS was confirmed by the postmortem tissue evaluation at autopsy. ${ }^{[20]}$

One of the most interesting finding of this study is all patients with stroke had comorbidity. The patients had on average six system related problems. Stroke and vascular system disorders were found to be the most frequently associated in $94.2 \%$ of patients. Hypertension was the most common disease in vascular system disorders. Stroke and endocrine system disorders such as diabetes mellitus, obesity and osteoporosis were the second common association with a frequency of $76.9 \%$. Stroke and psychiatric disorders were the third most commonly associated with a $69.2 \%$ frequency in this study. Depression was the most frequent of the psychiatric disorders. Giaguinto ${ }^{[21]}$ reported that the most common chronic problems associated with hemiplegia were cardiac disorders, followed by vascular disorders including mainly hypertension in stroke. In some studies, it was reported that the most common cluster of diseases were stroke and hypertension in older people. ${ }^{[6,7]}$

Carod-Artal et al. ${ }^{[22]}$ concluded that the mean CIRS total score was $7.6 \pm 5.2$ in patients with ischemic stroke, mean age 66.2 , in an international study. Moreover, they reported a positive relationship between the frequency of comorbidity and age. In another study, the most frequent comorbid conditions in patients with acute stroke were reported as hypertension, constipation, hyperlipidemia, diabetes

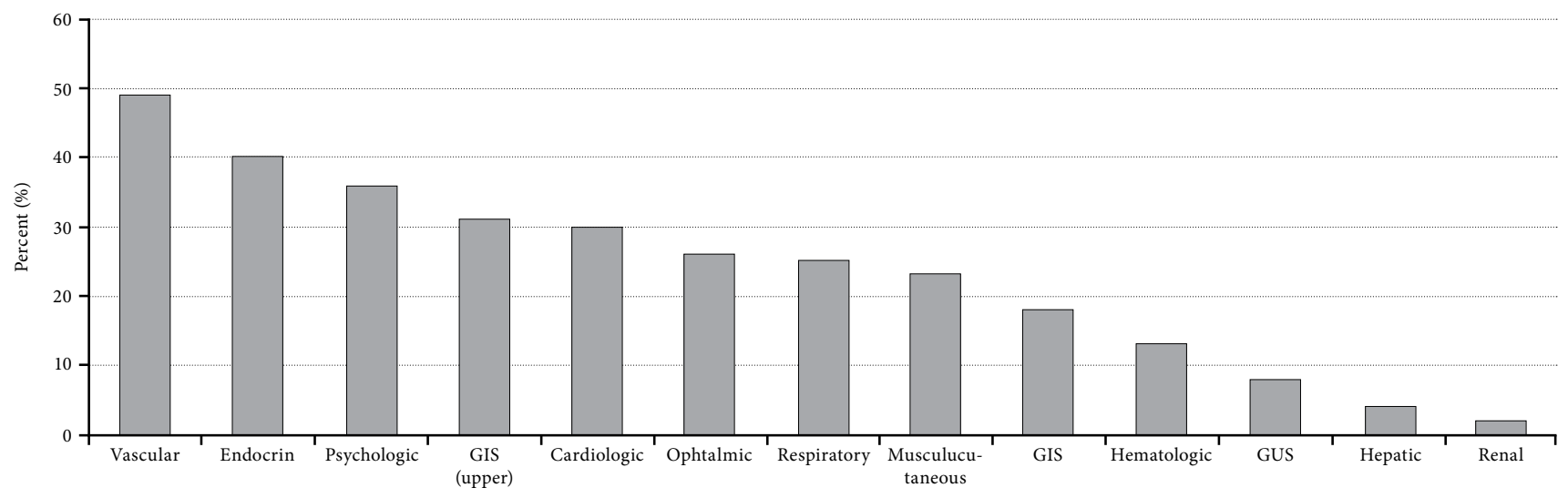

Figure 1. The causes of comorbidity in patients with stroke ( $\mathrm{n}=52)$. GIS: Gastrointestinal system; GUS: Genitourinary system. 
mellitus and electrocardiographic abnormalities, respectively. ${ }^{[23]}$

It may be possible to prevent comorbidity by clarifying the common underlying mechanisms in the clusters of diseases. ${ }^{[6]}$ The common pathogenetic mechanism of some chronic disorders coexisting in patients with multiple diseases have been well-defined. ${ }^{[9]}$ The coexistence of diabetes and hypertension was frequently reported in previous studies. ${ }^{[9,10]}$ Vascular complications are common in patients with both diabetes and hypertension. ${ }^{[10]}$

Stroke and hypertension were the most common disease combination in this study. Marengoni et al. ${ }^{[6]}$ defined five clusters concerning chronic system disorders in a study conducted in individuals aged $\geq 77$ years. The first was the cluster of vascular disorders constituted by hypertension, cardiac failure, atrial fibrillation and cerebrovascular diseases. This cluster was followed by the coexistence of thyroid disorders, chronic obstructive pulmonary diseases and coronary artery diseases; the cluster of diabetes, visual disorders and hearing loss; the coexistence of musculoskeletal and mental disorders including dementia, depression and hip fractures. The final cluster was malignancy and subsequently anemia.

Four multimorbidity patterns were found in patients $\geq 65$ years in the KORA (The Cooperative Health Research in the Region Augsburg) study. These were cardiovascular and metabolic disorders; joints, liver and pulmonary and ophthalmic disorders; gastrointestinal system disorders and cancers. In the same study, the most common disease combinations were reported as hypertension and diabetes mellitus; hypertension, stroke, hypertension along with other cardiac diseases. ${ }^{[7]}$ These results were similar with those of our studies. In our study, the most common diseases that accompany to stroke were hypertension, diabetes, obesity and osteoporosis.

Schäfer et al., ${ }^{[8]}$ concluded that comorbidity in elderly people appeared in two forms. The first one was the coexistence of cardiovascular and metabolic diseases that were frequently observed in lower income males, whereas the second one included somatic symptom disorders and morbidity related with pain that occurred equally in various age and income levels and was mostly observed in women. Whereas stroke and endocrine problems such as diabetes mellitus, obesity and osteoporosis combined were the second most common disease association, third one was stroke and depression association such as in our study.
One of the important findings of this study is the mean affected organ system number was more than six and the mean CIRS total score was 16 in patients with stroke. In a previous study the CIRS scores in women and men $\geq 65$ years were reported as 12.9 and 13.1, respectively. Even with the lack of a cutoff value for CIRS, 10 points indicates impairment in four or five systems. ${ }^{[4]}$ On the other hand, scores over 25-30 indicate severe impairment in several systems. ${ }^{[15]}$

Giaquinto et al., ${ }^{[24]}$ reported that CIRS scores were higher in patients with neurological disorders mainly stroke than that of patients with orthopedic problems in the rehabilitation setting. Di Libero et al. ${ }^{[25]}$ concluded that comorbidity was more frequent in stroke patients than those with hip fractures in a study using CIRS. The CIRS was reported to be a useful scale which could be used in the rehabilitation setting, while particularly suggesting the addition of a new item only for skin lesions from pressure ulcers, in the same study.

This study demonstrated strengths and suffered from limitations. The first strength of this study is that it is the first one in our knowledge that investigates the frequency of comorbidity in stroke in a rehabilitation setting in Turkey. Secondly, all patients were examined by the same physician. The first limitation of this study is the relatively small number of patients included. Secondly, the generalizability of the results. The number of stroke patients living in the community may be limited because the sample in this study was chosen from a rehabilitation hospital.

In conclusion, CIRS is a reliable tool for measuring comorbidity in patients with stroke and on average six different conditions were present in the participants in the rehabilitation setting. The disorders frequently associated with stroke were hypertension, diabetes, obesity and osteoporosis and depression in this study. The multidisciplinary approach to the rehabilitation process in stroke patients might be helpful for the increased success of the therapy.

\section{Acknowledgements}

I would like to thank to Dr. Nurhan İnce for the contribution of statistical analysis of the text.

\section{Declaration of conflicting interests}

The authors declared no conflicts of interest with respect to the authorship and/or publication of this article.

\section{Funding}

The authors received no financial support for the research and/or authorship of this article. 


\section{REFERENCES}

1. Valderas JM, Starfield B, Sibbald B, Salisbury C, Roland M. Defining comorbidity: implications for understanding health and health services. Ann Fam Med 2009;7:357-63.

2. Taylor AW, Price K, Gill TK, Adams R, Pilkington R, Carrangis N, et al. Multimorbidity - not just an older person's issue. Results from an Australian biomedical study. BMC Public Health 2010;10:718.

3. Britt HC, Harrison CM, Miller GC, Knox SA. Prevalence and patterns of multimorbidity in Australia. Med J Aust 2008;189:72-7.

4. Fortin M, Bravo G, Hudon C, Vanasse A, Lapointe L. Prevalence of multimorbidity among adults seen in family practice. Ann Fam Med 2005;3:223-8.

5. Marengoni A, Angleman S, Melis R, Mangialasche F, Karp A, Garmen A, et al. Aging with multimorbidity: a systematic review of the literature. Ageing Res Rev 2011;10:430-9.

6. Marengoni A, Rizzuto D, Wang HX, Winblad B, Fratiglioni L. Patterns of chronic multimorbidity in the elderly population. J Am Geriatr Soc 2009;57:225-30.

7. Kirchberger I, Meisinger C, Heier M, Zimmermann AK, Thorand B, Autenrieth CS, et al. Patterns of multimorbidity in the aged population. Results from the KORA-Age study. PLoS One 2012;7:30556.

8. Schäfer I, Hansen H, Schön G, Höfels S, Altiner A, Dahlhaus $A$, et al. The influence of age, gender and socio-economic status on multimorbidity patterns in primary care. First results from the multicare cohort study. BMC Health Serv Res 2012;12:89.

9. Meisinger C, Döring A, Heier M. Blood pressure and risk of type 2 diabetes mellitus in men and women from the general population: the Monitoring Trends and Determinants on Cardiovascular Diseases/Cooperative Health Research in the Region of Augsburg Cohort Study. J Hypertens 2008;26:1809-15.

10. Long AN, Dagogo-Jack S. Comorbidities of diabetes and hypertension: mechanisms and approach to target organ protection. J Clin Hypertens (Greenwich) 2011;13:244-51.

11. Smith SM, O'Dowd T. Chronic diseases: what happens when they come in multiples? Br J Gen Pract 2007;57:268-70.

12. Huntley AL, Johnson R, Purdy S, Valderas JM, Salisbury C. Measures of multimorbidity and morbidity burden for use in primary care and community settings: a systematic review and guide. Ann Fam Med 2012;10:134-41.
13. Linn BS, Linn MW, Gurel L. Cumulative illness rating scale. J Am Geriatr Soc 1968;16:622-6.

14. Miller MD, Paradis CF, Houck PR, Mazumdar S, Stack JA, Rifai AH, et al. Rating chronic medical illness burden in geropsychiatric practice and research: application of the Cumulative Illness Rating Scale. Psychiatry Res 1992;41:237-48.

15. Hudon C, Fortin M, Vanasse A. Cumulative Illness Rating Scale was a reliable and valid index in a family practice context. J Clin Epidemiol 2005;58:603-8.

16. Extermann M, Overcash J, Lyman GH, Parr J, Balducci L. Comorbidity and functional status are independent in older cancer patients. J Clin Oncol 1998;16:1582-7.

17. Rochon PA, Katz JN, Morrow LA, McGlinchey-Berroth $\mathrm{R}$, Ahlquist MM, Sarkarati M, et al. Comorbid illness is associated with survival and length of hospital stay in patients with chronic disability. A prospective comparison of three comorbidity indices. Med Care 1996;34:1093-101.

18. Waldman E, Potter JF. A prospective evaluation of the cumulative illness rating scale. Aging (Milano) 1992;4:171-8.

19. Hudon C, Fortin M, Soubhi H. Abbreviated guidelines for scoring the Cumulative Illness Rating Scale (CIRS) in family practice. J Clin Epidemiol 2007;60:212.

20. Conwell Y, Forbes NT, Cox C, Caine ED. Validation of a measure of physical illness burden at autopsy: the Cumulative Illness Rating Scale. J Am Geriatr Soc 1993;41:38-41.

21. Giaquinto S. Comorbidity in post-stroke rehabilitation. Eur J Neurol 2003;10:235-8.

22. Carod-Artal FJ, Casanova Lanchipa JO, Cruz Ramírez LM, Pérez NS, Siacara Aguayo FM, Moreno IG, et al. Stroke subtypes and comorbidity among ischemic stroke patients in Brasilia and Cuenca: a Brazilian-Spanish cross-cultural study. J Stroke Cerebrovasc Dis 2014;23:140-7.

23. Karatepe AG, Gunaydin R, Kaya T, Turkmen G. Comorbidity in patients after stroke: impact on functional outcome. J Rehabil Med 2008;40:831-5.

24. Giaquinto S, Palma E, Maiolo I, Piro MT, Roncacci S, Sciarra A, et al. Importance and evaluation of comorbidity in rehabilitation. Disabil Rehabil 2001;23:296-9.

25. Di Libero F, Fargnoli M, Pittiglio S, Mascio M, Giaquinto S. Comorbidity and rehabilitation. Arch Gerontol Geriatr 2001;32:15-22. 